\title{
General Counsel Prominence and Corporate Tax Policy
}

\author{
John L. Abernathy \\ Kennesaw State University \\ Thomas R. Kubick \\ Adi Masli \\ The University of Kansas
}

\begin{abstract}
Prior research provides evidence that individual executives have a significant effect on firm-level tax policy. Further research has shown that having a corporate general counsel (GC) in a firm's top management team (top five highest-paid executives) significantly affects a firm's accounting and disclosure practices. In this paper, we examine the role of the GC in corporate tax policy. Specifically, we use the ascension of the corporate GC to top management as the identifying event in which the role and influence of the corporate GC becomes more salient. We find strong evidence that GC ascension to top management is associated with an increase in tax aggressiveness, as evidenced by greater book-tax differences and a higher likelihood of engaging in tax shelter activities.
\end{abstract}

Keywords: general counsel; tax aggressiveness; tax sheltering; top management team.

Data Availability: Data are obtained from public sources identified in the paper.

\section{INTRODUCTION}

I $\mathrm{n}$ this paper, we examine the influence of the corporate general counsel (GC) over firm-level tax policy. The role of the GC as head of the corporate legal department has grown exponentially over the past three decades (DeMott 2005). Often, the GC has joined senior management at or near the top of the corporate hierarchy, and companies are increasingly using the GC, rather than outside counsel, for advising on legal matters (Heineman 2012). Recent research provides evidence that having a GC in the top management team significantly influences a company's regulatory compliance, control environment, financial reporting process, and disclosure practices (Jagolinzer, Larcker, and Taylor 2011; Kwak, Ro, and Suk 2012; Hopkins, Maydew, and Venkatachalam 2015). We extend this literature by investigating the role that the GC plays in corporate tax policy. ${ }^{1}$

Dyreng, Hanlon, and Maydew (2010) show that individual executives play a statistically and economically significant role in influencing tax outcomes. However, little is known about the extent to which the GC impacts the corporate tax policy of the firm (Hanlon and Heitzman 2010). ${ }^{2}$ This is surprising given that GCs participate in the negotiation, structure, documentation, and tax-related considerations of significant business transactions (Duggin 2007). Additionally, GCs are responsible for managing inside lawyers and outside counsel working on complex transactions, which often have significant tax implications (Heineman 2012).

We thank Kenneth J. Klassen (editor) and two anonymous reviewers for many helpful comments and suggestions. Professor Abernathy gratefully acknowledges a Research and Development Grant from the Coles College of Business at Kennesaw State University. Professors Kubick and Masli gratefully acknowledge financial support from The University of Kansas.

Editor's note: Accepted by Kenneth J. Klassen.

Submitted: May 2014

Accepted: August 2015

Published Online: August 2015

\footnotetext{
${ }^{1}$ We follow related tax research and define tax aggressiveness as the explicit reduction of a firm's tax liabilities that likely fall in the more aggressive end of the spectrum (Hanlon and Heitzman 2010). Such activities generate greater differences between book and taxable income (i.e., "book-tax differences"), thereby providing the firm with greater cash flows and earnings. We use two primary measures of tax aggressiveness: book-tax differences $(B T D)$ and tax sheltering likelihood (SHELTER). In our paper, we interpret a firm that exhibits greater tax aggressiveness as a firm with a more aggressive tax policy.

2 Armstrong, Blouin, and Larcker (2012) investigate, but find no significant relation between GC compensation and tax avoidance using a cross-sectional levels approach. In contrast, our study utilizes a difference-in-differences design, with the ascension of the GC to the top management team as our identifying event, to test the GC's influence over tax policy.
} 
While this literature suggests that the GC may affect a firm's tax liability, the overall effect of the GC on tax policy is unclear. The average GC is neither likely to be a tax expert, nor is she directly involved in the tax activities of the firm. However, a GC in the top management team may contribute in setting the overall tone for the firm's tax activities by interpreting the tax law and advising on compliance-related matters. From a practical standpoint, GCs advise the CEO and the executive team on strategic and operational decisions, as well as risk assessment, which influences the extent to which firms undertake risky activities (DeMott 2005; Heineman 2010). Furthermore, GCs may use their legal expertise to structure transactions to satisfy regulatory requirements, which could decrease the likelihood of detection (Nelson and Nielsen 2000; DeMott 2005). In this role as advisor, the GC can indirectly influence the daily activities of the tax director and other employees who are directly involved in the firm's tax decisions.

Consistent with prior research linking compensation to influence (Finkelstein 1992), we define the GC position to be a member of top management when the individual holding the position is among the top five highest-paid executives disclosed in the annual proxy filing. Being a member of the top management cohort, a GC is more likely to have stature, as well as access to the CEO, CFO, and other members of a company's senior management team, which offers the opportunity for the GC to influence significant corporate decisions as they are formulated and implemented (Duggin 2007; Deloitte 2010, 2011; Kwak et al. 2012). ${ }^{3}$ Accordingly, we use the ascension of the GC to the top management team to serve as our primary identifying event, as this theoretically represents a discernible shift in status, enabling the influence of the GC to become more salient and economically important. ${ }^{4}$

Using a sample spanning fiscal years 1993-2011, we provide evidence that the ascension of the GC to the top management team has a statistically and economically meaningful effect on corporate tax policy. We find that when GCs ascend into the top management team, there is a significant increase in the level of total book-tax differences (BTD), as well as the likelihood of engaging in tax sheltering activity (SHELTER). Visual inspection of the data reveals a discernable increase in BTD and SHELTER surrounding the year of ascension for GC firms relative to a control sample. Specifically, we observe an 11 percent increase in total book-tax differences and a 4 percent increase in tax sheltering likelihood in the year of ascension-an economically significant shift toward a more aggressive tax policy. ${ }^{5}$ In multivariate tests, we continue to observe a shift in tax policy after controlling for numerous factors that influence a firm's tax policy. Our results are robust to several specifications and design choices, including propensity score matching. We also investigate whether our results vary with the strength of a firm's corporate governance and do not find evidence that the relation between GC ascension and tax avoidance is magnified by weak corporate governance. Overall, our results show an increase in both book-tax differences and tax sheltering likelihood after GC ascension to top management, indicating a shift toward a more aggressive tax policy.

Our study makes several important contributions. First, we contribute to the growing literature investigating the determinants of tax policy. ${ }^{6}$ While prior work primarily examines the effects of firm-level characteristics on tax policy, an emerging line of research has begun to investigate executive-level effects on corporate tax outcomes (Dyreng et al. 2010; Armstrong et al. 2012; Rego and Wilson 2012). We focus our investigation on the influence of the GC, as this executive position is likely to have significant influence over regulatory compliance, including tax law. In doing so, we also answer a specific call for research by Hanlon and Heitzman (2010) to investigate the influence of the corporate GC in tax decisions. In a contemporaneous study, Goh, Lee, and $\mathrm{Ng}$ (2014) show an association between the presence of a GC in the top management team and contemporaneous tax avoidance. In our study, we focus on the ascension of the GC into top management and its effect on subsequent corporate tax outcomes. We employ a difference-in-differences design, which allows us to isolate the effect that GC ascension has on tax decisions in years subsequent to the ascension event.

Second, we add to the emerging line of research examining the role that the GC plays in financial reporting. Recent research provides evidence that the presence of the GC in the top management team has a significant influence on firms'

\footnotetext{
${ }^{3}$ For example, consider the following excerpt from the Association of the Bar of the City of New York's (2006) report of the task force on the lawyer's role in corporate governance:

"The General Counsel, to be effective, must be seen as a senior, influential, and respected officer of the corporation and member of the company's senior management ... His or her reporting relationships, access to management and the Board, and compensation all need to be consistent with senior status in the company."

4 Throughout this paper, we use "GC ascension" and "GC prominence" interchangeably. GCs become more economically important (i.e., "prominent") if their position is located near the top of the corporate hierarchy, and such prominence is empirically measurable when a firm discloses a GC within the top five highest-paid executive cohort in the annual proxy filing. We acknowledge, however, that data limitations preclude a thorough analysis of whether, and how, a GC's influence differs if they were promoted internally or hired externally. However, we present descriptive evidence using a hand-collected sample of GC ascensions that most GCs are promoted internally. Nevertheless, we use the phrase "GC ascension" to refer to internal promotions, as well as external hires.

5 An 11 percent increase in total book-tax differences roughly translates into $\$ 844$ million greater book-tax differences (mean lagged assets for our sample is $\$ 7,675$ million).

${ }^{6}$ See Shackelford and Shevlin (2001) and Hanlon and Heitzman (2010) for thorough reviews of this line of research.
} 
financial accounting and reporting practices (e.g., Kwak et al. 2012; Hopkins et al. 2015). Our results suggest that GCs in the top management team have a significant influence on firms' tax policy.

Finally, our study should also be of interest to regulators, auditors, executives (including practicing GCs), and investors. Corporate scandals involving the GCs of Tyco International Ltd., Comverse Technology, Inc., McAfee, and Enron have brought about increased scrutiny on the GC in promoting corporate ethical responsibility. ${ }^{7}$ Furthermore, the role and influence of the GC is highlighted in the Sarbanes-Oxley Act of 2002 (SOX) provisions and the Public Company Accounting Oversight Board (PCAOB) auditing standards. While there is much debate on GC influence and responsibility for corporate regulatory compliance, our results show that ascension of the GC position into top management is positively associated with a shift toward a more aggressive tax policy.

The rest of this paper is organized as follows. The second section reviews the related research and develops our hypothesis. The third section describes the sample selection process and details our research methodology. The fourth and fifth sections present our results, and the sixth section briefly concludes our study.

\section{BACKGROUND AND HYPOTHESIS DEVELOPMENT}

\section{Corporate Tax Policy}

Corporate tax policy has been a topic of interest for academics and regulators for decades. ${ }^{8}$ Prior research has investigated how to measure tax outcomes (e.g., Dyreng, Hanlon, and Maydew 2008; Hanlon and Heitzman 2010), the firm-level determinants of tax outcomes (Gupta and Newberry 1997; Mills, Erickson, and Maydew 1998; Shackelford and Shevlin 2001; Rego 2003; S. Chen, X. Chen, Cheng, and Shevlin 2010; McGuire, Omer, and Wang 2012; Cheng, Huang, Li, and Stanfield 2012; Graham, Hanlon, Shevlin, and Shroff 2014), and the consequences of tax outcomes (Desai and Dharmapala 2009; Hanlon and Slemrod 2009; Graham and Tucker 2006; Kim, Li, and Zhang 2011; Jennings, Weaver, and Mayew 2012; Hasan, Hoi, Wu, and Zhang 2014). Our study contributes to the emerging stream of research investigating the influence of individual executives on corporate tax policy (Dyreng et al. 2010; Armstrong et al. 2012; Graham et al. 2014) and, given the unique expertise and skill set of GCs, we answer a specific call in Hanlon and Heitzman (2010) for research investigating the influence of the GC in tax decisions. ${ }^{9}$

\section{Background of General Counsel Roles and Responsibilities}

The GC, as the individual with the most direct and comprehensive responsibility for the legal and ethical aspects of an entity's operation, has considerable influence on the "tone at the top" of a corporation (Duggin 2007). As DeMott (2005, 955956) suggests, a corporate GC has influence that may extend well beyond the bare bones of ensuring legal compliance and, therefore, "may be uniquely well positioned to champion a transformation of the organizational culture that shapes how the corporation addresses its relationships with law and regulation." ${ }^{10}$ In serving this role, the GC assumes key responsibilities, which include: (1) advising top management on legal issues; (2) managing litigation risk; and (3) monitoring top management's adverse actions against shareholders' interests (Duggin 2007; Deloitte 2010, 2011; Jagolinzer et al. 2011; Kwak et al. 2012). ${ }^{11}$

Furthermore, the amendments to the Model Rule of Professional Responsibility Rule 1.13 adopted by the American Bar Association (ABA 2003), the Securities and Exchange Commission (SEC) Rules and Regulations Part 205, and Sarbanes-

\footnotetext{
${ }^{7}$ Veasey and Di Guglielmo $(2012,63)$ are particularly informative: "The general counsel's involvement in business strategy and offering business advice can create pressure, often asserted by corporate managers, on the lawyer to enable transactions rather than to act as a "bottleneck" to getting the deal done. A corporate culture that emphasized getting the deal done quickly with too little regard for getting the deal done in an ethically and legally appropriate manner-and company lawyers' inability or unwillingness to apply the brakes - may have been a factor contributing to the corporate scandals around the turn of the twenty-first century." In our paper, we employ a difference-in-differences design with firm fixed effects in order to purge the potential confounding effects of corporate culture.

8 See Shackelford and Shevlin (2001) and, more recently, Hanlon and Heitzman (2010) for broad surveys of the literature.

${ }^{9}$ Recent studies have investigated the effects of certain managerial characteristics on tax outcomes, including personal tax preferences (Chyz 2013), military experience (Law and Mills 2013), overconfidence (Chyz, Gaertner, Kausar, and Watson 2014), managerial ability (Koester, Shevlin, and Wangerin 2014), and narcissism (Olsen and Stekelberg 2016).

${ }^{10}$ Brown (2003) provides survey evidence consistent with this notion, in that corporations hire in-house attorneys to prevent the company from being involved in litigation. Furthermore, Duggin (2007) notes that the GC has a professional obligation for oversight of all legal aspects of the corporation's operation and governance. A recent report by Deloitte (2011) also suggests that GCs are increasingly being relied upon to provide counsel on risk management and corporate ethics.

11 The GC is uniquely positioned to ensure that the basic corporate structure, governance documents, and compliance environment of the company meet the evolving standards of shareholder constituents and ratings agencies (Foley \& Lardner LLP 2010). Additionally, the GC has the primary responsibility for corporate legal matters and is in the best position to know and describe the status of all litigation, claims, and assessments, or to corroborate information furnished by management (Rostain 2008). In addition, GCs often have the practical ability to change an entity's direction by raising objections to a planned course of action (Winders 2005).
} 
Oxley (SOX) Section 307 have imposed specific requirements for GCs to be more accountable and take a broader view of their responsibilities, particularly with regard to shareholder interests (Schneider 2003; Duggin 2007; Rostain 2008). This broadening view extends to various financial accounting and reporting decisions of the firm. For example, Kwak et al. (2012) document that firms with a GC in top management are more likely to issue management earnings forecasts that are less optimistic and more accurate, concluding that prominent GCs play an important monitoring role in their company's disclosure policies. In addition, Jagolinzer et al. (2011) provide evidence that GCs limit the extent to which corporate insiders use their private information to extract rents from shareholders.

\section{General Counsel and Corporate Tax Policy}

The corporate tax setting can be particularly informative in investigating the role of the GC. On one hand, many firms may employ GCs that are well-versed in tax matters and rely on these individuals to assist in considering the tax implications of various transactions (Fleischer 2006; Duggin 2007). ${ }^{12}$ On the other hand, it is likely that the average GC is neither a tax expert, nor is she directly involved in the tax activities of the firm. However, based on the roles of the GC in the top management team, the GC may contribute to setting the overall tone for the firm's tax activities.

According to DeMott (2005), GCs serve three primary roles in an organization. Specifically, they act as business advisors, legal advisors, and as agents in transactions with outside parties. As business advisors, GCs are responsible for consulting the $\mathrm{CEO}$ on risk assessment, strategic direction, accounting decisions, and the firm's engagement in risky activities (Heineman 2010). As legal advisors, GCs advise the executive team on how to structure transactions in a manner that satisfies regulatory requirements, which reduces the possibility of scrutiny or detection by oversight bodies (Nelson and Nielsen 2000). Finally, as an agent of the firm, the GC can affect the probability and severity of legal penalties through the effectiveness of her advocacy (Heineman 2010).

In fulfilling these roles, particularly as business and legal advisor, the GC can indirectly influence the daily activities of the tax director and other employees who are directly involved in the firm's tax decisions. For example, a recent survey of tax directors indicated that the lack of a valid business purpose and/or economic substance was the most important reason why a proposed tax planning strategy was not implemented (Graham et al. 2014). ${ }^{13}$ Such a determination would likely be made in conjunction with the GC as a business and legal advisor.

Tax aggressiveness has been described as a risky activity, imposing a variety of costs on firms and managers (e.g., Hanlon and Slemrod 2009; Chen et al. 2010; Kim et al. 2011; Rego and Wilson 2012; Graham et al. 2014), and because tax aggressiveness is a costly and risky activity, GCs are in a unique position to assist top management in assessing risks related to aggressive tax strategies. It is unclear ex ante whether GCs will be strict compliance monitors that dissuade firms from taking aggressive tax positions or if they will advise and advocate for management in the pursuit of lower tax liabilities. ${ }^{14}$

\section{Hypothesis Development}

We posit that ascension of the GC into the top management team will be associated with changes in corporate tax aggressiveness. Remarks by both former and current Internal Revenue Service (IRS) commissioners (i.e., Doug Shulman and Steven Miller) have suggested that there can be significant reputational and public relations danger associated with overly aggressive tax avoidance strategies, and this concern was confirmed in a recent survey of tax directors (Graham et al. 2014). If the GC emphasizes strengthening the control environment, increasing management's awareness for regulatory compliance, and protecting the reputation of the corporation, then we should observe a negative association between the promotion of the GC into top management and measures of tax aggressiveness.

However, tax aggressiveness can reduce tax liabilities, which can increase cash flows and net income. Graham et al. (2014) provide survey evidence suggesting that companies use tax planning as a means to enhance accounting earnings. They find that 71 percent (57 percent) of surveyed publicly traded companies indicate that it is important for a tax strategy to not reduce earnings per share (to actually lead to higher earnings per share). Further, taxes represent a significant cost to the firm and, therefore, are subject to management discretion. Hence, tax avoidance activities undertaken by management may be in the interest of shareholders. If the GC's rise into top management results in advising and advocating management's (as well as the

${ }^{12}$ See Fleischer (2006) for a discussion of the role of in-house counsel in the options backdating scandal.

13 Reputational concerns and detection risk were ranked as the second and third most important reasons, respectively. Such sentiment is consistent with explanations for the "under-sheltering puzzle" discussed in Weisbach (2002).

${ }^{14}$ We focus on prominent GCs (i.e., GCs who have ascended into the top five highest-paid executive cohort), as the influence these GCs have in the executive team becomes more salient. That is, GCs in top management may hold greater power and influence over the CEO and top management, relative to less prominent GCs. 
GC's) preferences for more aggressive tax policies, then we expect the ascension of the GC into top management to be accompanied with an increase in tax aggressiveness. ${ }^{15}$

In sum, the association between GC ascension and tax aggressiveness is unclear ex ante. Hence, we formulate our hypothesis, stated in alternate form, as non-directional:

H: The ascension of the GC into the top management team is associated with a change in corporate tax aggressiveness.

\section{SAMPLE AND RESEARCH METHODOLOGY}

\section{Sample}

We build our sample from the intersection of the Execucomp and Compustat North American databases. We limit our sample to include domestically incorporated, publicly traded firms. Due to inherent legal and regulatory differences, financial firms and utilities are omitted from the analyses. We also delete firms with reported assets less than $\$ 1$ million to combat the small deflator problem (Chen et al. 2010), and we delete firms with negative pretax income as these firms are in an inherently different tax position relative to other firms. Execucomp further constrains our analysis to begin in fiscal year 1993. Our final sample consists of 7,028 firm-year observations spanning fiscal years 1993 through 2011.

Table 1 reports our sample composition. Panel A indicates a fairly even distribution of observations across time. ${ }^{16}$ Panel B reports the time distribution of GC ascensions. As we describe below, we require GCs to be in the top management team for at least two years after ascension in order to have a credible influence on corporate tax policy and to shed the effects of transitory variation in top management team ascensions. Thus, our final year to identify a GC ascension is 2009. GC ascensions can vary by year, ranging from 14 in 1998 to 39 in 2001. Panel C reports the industry distribution of our sample. We note a cluster of firms in SICs that begin with 2 (food, tobacco, textiles, paper, and chemicals) and SICs that begin with 3 (manufacturing, machinery, and electronics); however, we control for industry at a more refined level in analyses that require industry fixed effects.

\section{Identification of General Counsel Ascension}

We test whether the ascension of the GC into top management is associated with a change in tax policy. We focus our attention on GC ascension as the identifying event because the influence of the corporate GC is likely to become more salient. Thus, we identify a GC firm as a firm that has ascended its corporate GC to top management. To ensure that our results are not biased by transitory changes in the composition of the top management team, and to ensure that the GC has enough time to have an influence in corporate tax policy, we require the GC to remain in the top management team for at least two years after the year of ascension.

As we discuss later, we are not simply interested in whether GC firms, on average, report lower tax liabilities than non-GC firms (a "firm effect"). Rather, we are interested in whether a shift in status is accompanied by a change in tax policy, since the underlying economic conflicts facing the GC role arguably become more salient when the GC ascends to top management (i.e., a "difference-in-differences" design). This results in a more powerful test since we are using the economic event (GC ascension) as our pivot point in measuring the impact that GCs have on tax policy, rather than documenting a cross-sectional difference in taxes between GC firms and non-GC firms, which is likely to be affected by a number of potentially confounding factors.

We identify GC firms using the Execucomp database, which tracks compensation information on top executives disclosed in annual proxy filings for the Standard \& Poor's (S\&P) 1500. Consistent with prior research that has linked executive compensation to influence within the organization (Finkelstein 1992), we define a GC to be in top management when he or she becomes one of the top five highest-paid executives of the firm. ${ }^{17}$ Consistent with prior research (e.g., Kwak et al. 2012; Hopkins et al. 2015) that examines GC ascension into top management, we search the Execucomp database for executives that are listed among the top five highest-paid executives during the year, and identify an executive as a "GC" if the title contains the word "counsel," "law," or "legal."18

\footnotetext{
${ }^{15}$ It is possible that a positive association between GC ascension and tax aggressiveness may be the result of management's intention to adopt a more aggressive tax policy, thereby necessitating a GC in the top management team to support and advise on specific transactions and tax positions.

16 We note a smaller number of firms in 1993 attributable to our use of lagged Execucomp measures and the limited coverage in the Execucomp database in 1992.

${ }^{17}$ For some firm-years, Execucomp provides more than five executives. In those instances, we only consider the top five executives in our analyses.

${ }^{18}$ We also consider titles that include "gen. couns," or "gen couns." In addition, we eliminate titles that include the word "former."
} 
TABLE 1

\section{Sample Composition}

Panel A: Time Distribution of Full Sample

\begin{tabular}{l} 
Fiscal Year \\
\hline 1993 \\
1994 \\
1995 \\
1996 \\
1997 \\
1998 \\
1999 \\
2000 \\
2001 \\
2002 \\
2003 \\
2004 \\
2005 \\
2006 \\
2007 \\
2008 \\
2009 \\
2010 \\
2011
\end{tabular}

$\frac{\text { Freq. }}{100}$

249

296

339

351

360

402

434

406

416

416

445

444

429

415

387

361

399

379

Panel B: Time Distribution of GC Ascensions

\begin{tabular}{l} 
Fiscal Year \\
\hline 1996 \\
1997 \\
1998 \\
1999 \\
2000 \\
2001 \\
2002 \\
2003 \\
2004 \\
2005 \\
2006 \\
2007 \\
2008 \\
2009
\end{tabular}

\begin{tabular}{c} 
Freq. \\
\hline 15 \\
21 \\
14 \\
22 \\
25 \\
39 \\
21 \\
26 \\
23 \\
23 \\
25 \\
23 \\
23 \\
37
\end{tabular}

Panel C: Industry Distribution of Full Sample

\section{Industry (One-Digit SIC)}

0-1 (Agriculture, mining, oil, and construction)

2 (Food, tobacco, textiles, paper, and chemicals)

3 (Manufacturing, machinery, and electronics)

4 (Transportation and communications)

5 (Wholesale and retail)

7 (Services)

8-9 (Health, legal and educational services, and other)

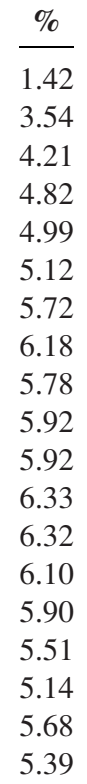

\begin{tabular}{c} 
Total Freq. \\
\hline 100 \\
349 \\
645 \\
984 \\
1,335 \\
1,695 \\
2,097 \\
2,531 \\
2,937 \\
3,353 \\
3,769 \\
4,214 \\
4,658 \\
5,087 \\
5,502 \\
5,889 \\
6,250 \\
6,649 \\
7,028
\end{tabular}

Total \%

1.42

4.97

9.18

14.00

19.00

24.12

29.84

36.01

41.79

47.71

53.63

59.96

66.28

72.38

78.29

83.79

88.93

94.61

100.00

Total Freq.

$\frac{\%}{4.45}$

6.23

4.15

6.53

7.42

11.57

6.23

7.72

6.82

6.82

7.42

6.82

6.82

10.98
Total \%

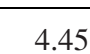

10.68

14.84

21.36

28.78

40.36

46.59

54.30

61.13

67.95

75.37

82.20

89.02

100.00

\begin{tabular}{c}
$\begin{array}{c}\text { Cumulative } \\
\text { Freq. }\end{array}$ \\
\hline 449 \\
2,208 \\
4,418 \\
4,738 \\
5,967 \\
6,660 \\
7,028
\end{tabular}

\begin{tabular}{c}
$\begin{array}{c}\text { Cumulative } \\
\%\end{array}$ \\
\hline $6.39 \%$ \\
$31.42 \%$ \\
$62.86 \%$ \\
$67.42 \%$ \\
$84.90 \%$ \\
$94.76 \%$ \\
$100.00 \%$
\end{tabular}




\section{Tax Aggressiveness}

Because we are interested in testing whether prominent GCs influence corporate tax policy, we use two measures that tax research considers to be manifestations of tax aggressiveness (Hanlon and Heitzman 2010; Rego and Wilson 2012; Armstrong et al. 2012). These measures allow for a stronger manipulation in our empirical design, as a corporate tax policy characterized by more aggressive tax avoidance is likely to be more salient to the GC than less aggressive policies. Our first measure is the level of total book-tax differences $(B T D)$, computed as pretax income less minority interest in earnings less taxable income $\left(\right.$ Compustat $\left.\mathrm{PI}_{i, t}-\mathrm{MII}_{i, t}-\left(\mathrm{TXFED}_{i, t}+\mathrm{TXFO}_{i, t}\right) / 0.35\right)$, scaled by lagged total assets $\left(\right.$ Compustat $\left.\mathrm{AT}_{i, t-1}\right){ }^{19}{ }^{19} \mathrm{BT}$ provides a measure of the extent to which book income exceeds taxable income. Our second measure, tax sheltering likelihood (SHELTER), is measured by reversing the logit transform and using the coefficient estimates from the tax sheltering prediction model in Wilson $(2009,988)$, specifically, $-4.29+8.49 * B T D-0.76 * L E V+0.51 * S I Z E+4.59 * R O A+1.28 * F I+5.24 *$ $R \& D .^{20}$ Thus, SHELTER reflects a probability ranging from 0 to 1 . Higher values of BTD and SHELTER reflect greater tax aggressiveness and, thus, a more aggressive corporate tax policy. ${ }^{21}$

\section{Multivariate Design}

We test our hypothesis by estimating variations of the following regression model:

$$
\begin{aligned}
(B T D \text { or SHELTER })= & \alpha_{0}+\alpha_{1} \text { GCFIRM }+\alpha_{2} \text { POST }+\alpha_{3} \text { GCFIRM } * \text { POST }+ \text { Controls }+ \text { fiscal year and firm fixed effects } \\
& +\varepsilon
\end{aligned}
$$

Because we are interested in whether GC ascension is associated with a change in corporate tax policy, we estimate Equation (1) using a difference-in-differences design. This allows us to test the extent to which GC ascension (an empirically measurable event in which the economic conflicts surrounding the GC role become more salient) is associated with an observable shift in tax policy. Hence, our variable of interest is GCFIRM * POST, our difference-in-differences estimator, in this specification. The idea behind Equation (1) is to isolate the impact of ascending a GC into top management on subsequent tax aggressiveness, while controlling for the average tax effects arising from other factors (e.g., profitability, financial reporting aggressiveness, size, foreign operations, earnings reported under the equity method, intangibles, capital intensity, net operating losses [NOLs], growth opportunities, leverage, and research and development [R\&D]).

$B T D$ represents total book-tax differences and SHELTER represents our empirical proxy for tax sheltering likelihood described earlier. GCFIRM equals 1 if the firm ascended a GC at any point in time during our sample period. POST equals 1 for fiscal years beginning with the year of GC ascension. Our choice of control variables is motivated by related tax research (Chen et al. 2010; McGuire et al. 2012; Cheng et al. 2012; Rego and Wilson 2012). ${ }^{22}$

CEO option sensitivities to stock prices (Delta) and stock volatility (Vega) — common measures of equity incentivesare included as controls, as Rego and Wilson (2012) show that CEO equity incentives are positively associated with tax aggressiveness. Specifically, Delta (Vega) is estimated as the dollar increase in a CEO's option portfolio given a \$1 (0.01 unit) increase in stock price (volatility). ${ }^{23}$ Prior research shows that higher Vega (Delta) encourages (discourages) managerial risk-taking (Knopf, Nam, and Thornton 2002; Coles, Daniel, and Naveen 2006; Brockman, Martin, and Unlu 2010; Armstrong, Larcker, Ormazabal, and Taylor 2013). Thus, we predict positive (negative) coefficient loadings on $C E O$ Vega (CEO Delta). We lag these values in our regressions and log-transform them in order to mitigate the influence of outliers.

Return on assets, $R O A$, computed as pretax income (Compustat $\left.\mathrm{PI}_{i, t}\right)$ divided by lagged total assets $\left(\right.$ Compustat $\left.\mathrm{AT}_{i, t-1}\right)$, is included to control for tax differences related to profitability. Consistent with prior research, we expect to observe a positive coefficient loading on ROA (Rego 2003). We include performance-matched pretax discretionary accruals, $A C C$, to control for the positive association with financial reporting aggressiveness (Frank, Lynch, and Rego 2009). SIZE is computed as the natural logarithm of sales (Compustat $\mathrm{SALE}_{i, t}$ ). We expect to observe a positive coefficient loading on SIZE as it proxies for

\footnotetext{
19 If TXFED is missing, then we estimate taxable income as total tax expense less state and foreign taxes.

${ }^{20}$ Specifically, BTD equals total book-tax differences less the change in net operating loss; LEV equals long-term debt divided by assets (Compustat $\left.\operatorname{DLTT}_{i, t} / \mathrm{AT}_{i, t}\right)$; SIZE equals the natural logarithm of total assets (Compustat $\left.\mathrm{AT}_{i, t}\right) ; R O A$ equals pretax income divided by assets $\left(\mathrm{Compustat}^{\mathrm{PI}} \mathrm{I}_{i, t} / \mathrm{AT}_{i, t}\right)$; $F I$ equals 1 if pretax foreign income (Compustat $\mathrm{PIFO}_{i, t}$ ) is positive; and $R \& D$ equals total research and development expenses divided by lagged assets (Compustat $\mathrm{XRD}_{i, t} / \mathrm{AT}_{i, t-1}$.

21 Another interpretation of SHELTER is a firm's propensity to contest a tax shelter's legal validity in court. Thus, a positive result could reflect a GC's influence in interpreting and defending the legal validity of tax sheltering transactions. We thank an anonymous referee for this comment.

${ }^{22}$ For ease of exposition, variable definitions are provided in Table 2.

23 We follow the Core and Guay (2002) "one year approximation" method to estimate Delta and Vega.
} 
resources for tax planning (Mills et al. 1998). We include foreign income, FI, computed as pretax income from foreign operations (Compustat $\mathrm{PIFO}_{i, t}$ ) divided by lagged total assets $\left(\right.$ Compustat $\mathrm{AT}_{i, t-1}$ ), to control for tax differences related to foreign operations. We expect to observe a positive association between $F I$ and tax aggressiveness (Rego 2003). EQINC equals 1 if equity in earnings (Compustat $\mathrm{ESUB}_{i, t}$ ) is positive, in order to control for differences in tax treatment of earnings reported under the equity method. INTAN is computed as reported intangibles (Compustat INTAN ${ }_{i, t}$ ) divided by lagged total assets (Compustat $\mathrm{AT}_{i, t-1}$ ). We expect positive coefficient loadings on EQINC and INTAN (Chen et al. 2010). PPE is net property, plant, and equipment (Compustat PPENT ${ }_{i, t}$ ), scaled by lagged total assets (Compustat $\mathrm{AT}_{i, t-1}$ ), to control for tax differences related to capital intensity. We expect to observe a positive coefficient loading on PPE (Gupta and Newberry 1997). NOL is equal to 1 if the firm reports a positive tax loss carryforward $\left(\mathrm{Compustat}^{\mathrm{T}} \mathrm{LCF}_{i, t}\right)$, and 0 otherwise, to control for the positive association between NOL usage and tax aggressiveness. We also include the change in NOL, scaled by lagged assets, as an additional control $(\triangle N O L)$.

We control for tax differences related to growth opportunities using the market-to-book ratio, MTB, which is computed as lagged market value of equity (Compustat PRCC_ $\mathrm{F}_{i, t-1} * \mathrm{CSHO}_{i, t-1}$ ) divided by book value of equity (Compustat $\mathrm{CEQ}_{i, t-1}$ ). We are agnostic as to the directional expectation for MTB. Leverage, $L E V$, is computed as total long-term debt (Compustat $\mathrm{DLTT}_{i, t}$ ) divided by lagged total assets (Compustat $\mathrm{AT}_{i, t-1}$ ) to control for tax differences related to debt usage. We expect to observe a negative coefficient loading on $L E V$ (Graham and Tucker 2006). $R \& D$ is computed as research and development expense (Compustat $\mathrm{XRD}_{i, t}$ ) divided by lagged total assets (Compustat $\mathrm{AT}_{i, t-1}$ ) to control for the positive tax benefits related to $\mathrm{R} \& \mathrm{D}$. Industry indicators (based on two-digit SIC) and fiscal year indicators are included, and standard errors are clustered by firm. ${ }^{24}$ Finally, Equation (1) is estimated using firm fixed effects in order to estimate a within-firm change in tax policy surrounding the appointment of a GC to the top management team.

\section{RESULTS}

\section{Figure 1}

Figure 1 depicts the mean book-tax differences (BTD) and tax sheltering likelihood (SHELTER) for fiscal years surrounding the year of ascension (year $t$ ) for GC firms (Treatment), as well as a propensity score matched sample of control firms (Control), as described in more detail below. The figure reveals a striking pattern. Firms that ascend a GC to the top management team exhibit a clear increase in book-tax differences (BTD), as well as tax sheltering likelihood (SHELTER). Specifically, mean book-tax differences (BTD) in year $t$ and in year $t-1$ are 0.0273 and 0.0245 , respectively. This represents an 11 percent increase in book-tax differences in the year of ascension. Similarly, mean tax sheltering likelihoods (SHELTER) in year $t$ and year $t-1$ are 0.683 and 0.655 , respectively, which roughly equates to a 4 percent increase in tax sheltering likelihood. In contrast, control firms exhibit a negligible increase in SHELTER and a decrease in BTD. These patterns provide some preliminary support for GC ascension being associated with a more aggressive corporate tax policy. ${ }^{25}$

\section{Descriptive Statistics}

Table 2 presents the descriptive statistics for the variables used to specify our multivariate models. Mean and median of $B T D$ are 0.025 and 0.020 , respectively, which is generally consistent with related tax research using book-tax differences (e.g., McGuire et al. 2012). Mean and median SHELTER are 0.687 and 0.741, respectively. Mean (median) CEO Delta and CEO $V e g a$ are $\$ 786,117(\$ 243,692)$ and $\$ 148,568$ (\$56,213), respectively, which is broadly consistent with prior research (e.g., Coles et al. 2006; Brockman et al. 2010; Rego and Wilson 2012). ${ }^{26}$ As mentioned previously, we log-transform these measures to mitigate the influence of outliers. Finally, means and medians of the remaining control variables are generally consistent with similar tax-related research (e.g., Chen et al. 2010; McGuire et al. 2012; Rego and Wilson 2012).

\section{Correlations}

Table 3 presents a correlation matrix of the variables used to specify Equation (1). Pearson (Spearman) correlation coefficients are reported below (above) the diagonal, and bolded coefficients denote significance at the 5 percent level or less using a two-sided test. As expected, BTD and SHELTER are positively and significantly correlated, suggesting that they capture

\footnotetext{
24 Time subscripts are included in all tables to clearly identify our use of contemporaneous and lagged variables.

${ }^{25}$ We also observe an increase in BTD and SHELTER after the year of ascension, suggesting that there may be a lagged effect, perhaps due to synergies between the GC and the top management team.

${ }^{26}$ We note, however, that Rego and Wilson (2012) use different terminology. Specifically, "CEO_SLOPE" and "CEO_RISK_INCENT" in their study are analogous to "CEO Delta" and "CEO Vega" in our study, respectively.
} 
FIGURE 1

Tax Avoidance in Years Surrounding GC Ascension

Panel A: BTD

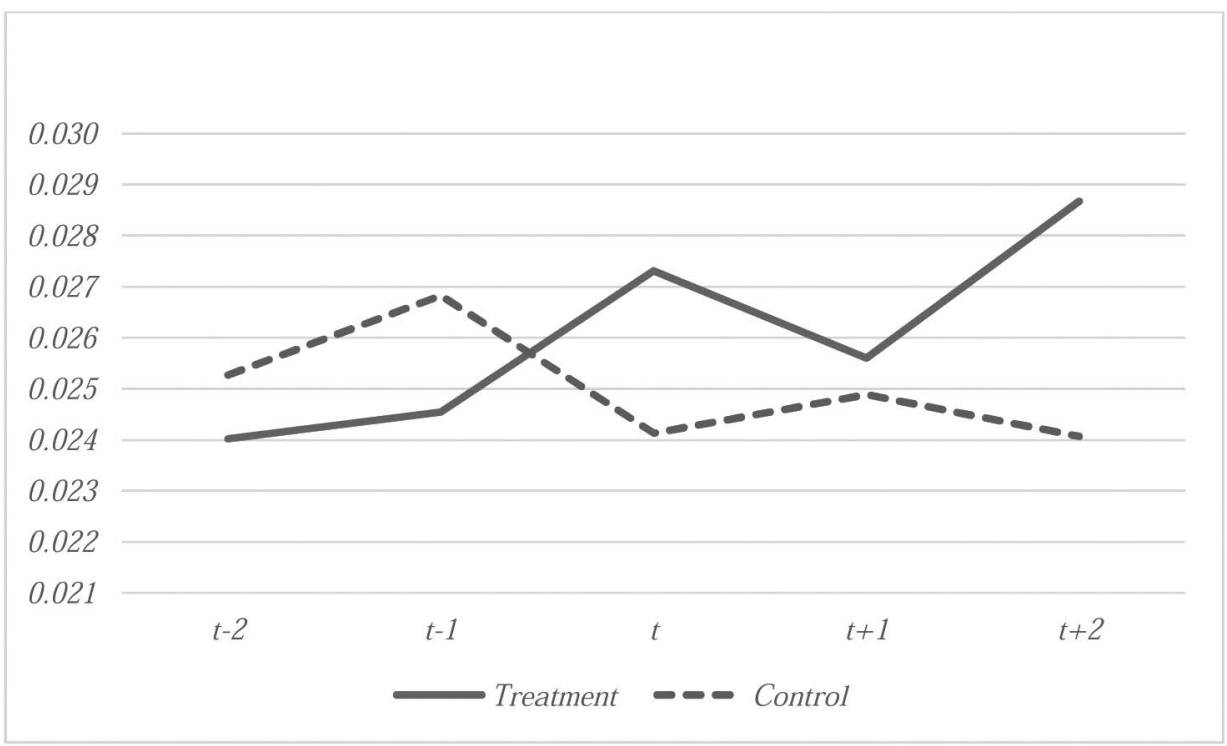

Panel B: SHELTER

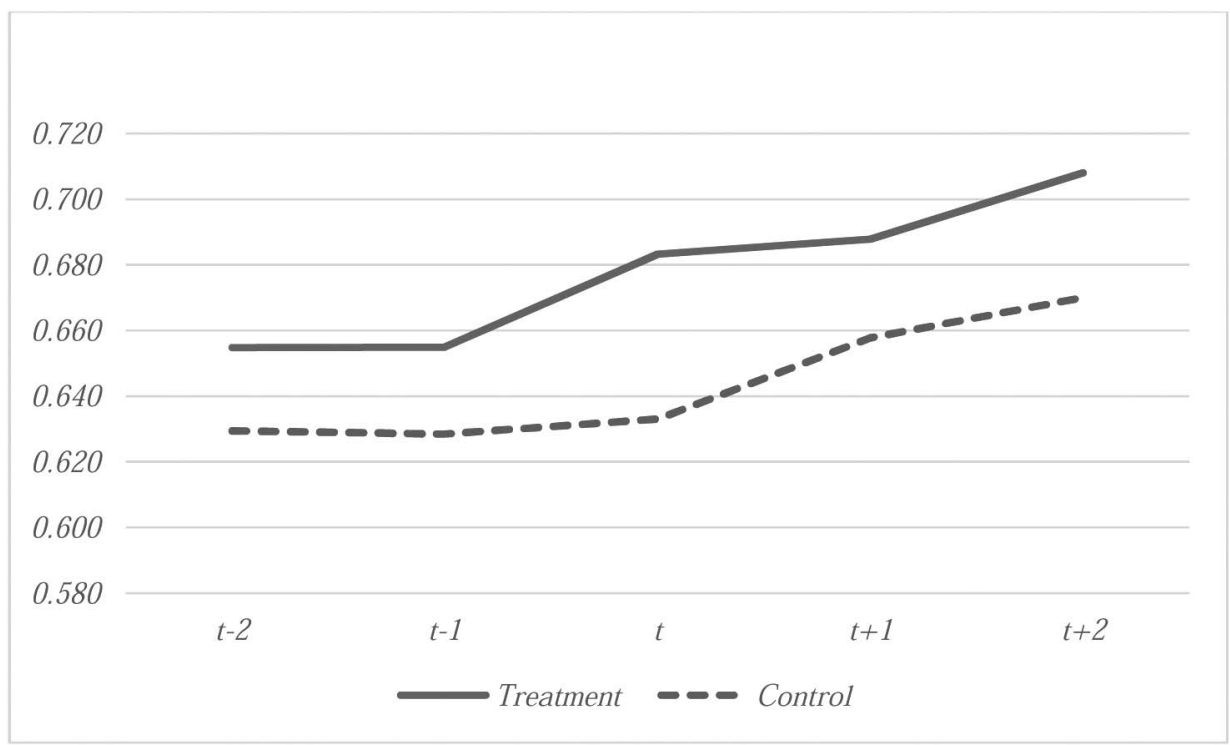

These graphs depict book-tax differences (BTD) and tax sheltering likelihood (SHELTER) during years before and after the ascension of a GC to the top management team (Treatment) or a matched firm that appears similar on observable characteristics, but did not ascend their GC (Control). 
TABLE 2

Descriptive Statistics

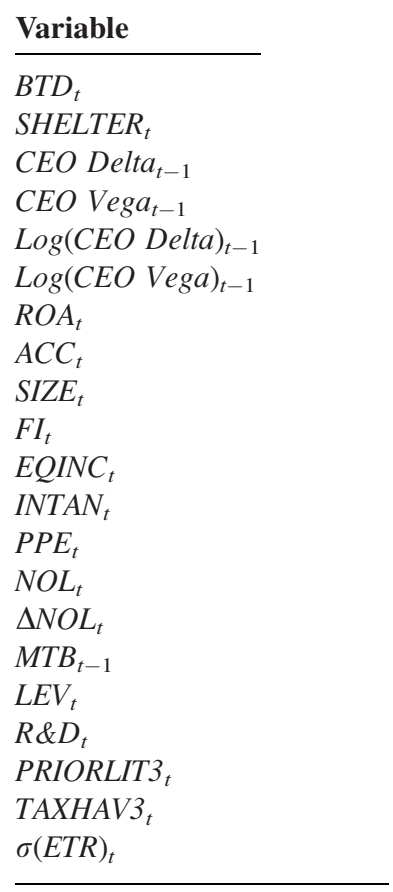

\begin{tabular}{c}
$\mathbf{n}$ \\
\hline 7,028 \\
7,028 \\
7,028 \\
7,028 \\
7,028 \\
7,028 \\
7,028 \\
7,028 \\
7,028 \\
7,028 \\
7,028 \\
7,028 \\
7,028 \\
7,028 \\
7,028 \\
7,028 \\
7,028 \\
7,028 \\
7,028 \\
7,028 \\
6,345
\end{tabular}

\begin{tabular}{r} 
Mean \\
\hline 0.025 \\
0.687 \\
786.117 \\
148.568 \\
5.330 \\
3.693 \\
0.125 \\
-0.009 \\
7.615 \\
0.027 \\
0.220 \\
0.193 \\
0.331 \\
0.357 \\
0.002 \\
3.467 \\
0.205 \\
0.025 \\
0.475 \\
0.533 \\
0.251
\end{tabular}

\begin{tabular}{r} 
Std. Dev. \\
\hline 0.044 \\
0.220 \\
1922.670 \\
250.538 \\
1.883 \\
1.975 \\
0.083 \\
0.055 \\
1.370 \\
0.041 \\
0.415 \\
0.209 \\
0.255 \\
0.479 \\
0.030 \\
3.324 \\
0.176 \\
0.042 \\
0.499 \\
0.499 \\
1.433
\end{tabular}

10th Pctl.

$-0.019$

0.352

24.404

0.000

3.235

0.000

0.035

$-0.072$

5.956

0.000

0.000

0.000

0.077

0.000

$-0.006$

1.297

0.000

0.000

0.000

0.000

0.007

$\begin{array}{rrr}\text { 50th Pctl. } & \text { 90th Pctl. } \\ 0.020 & 0.075 \\ 0.741 & 0.939 \\ 243.692 & 1617.400 \\ 56.213 & 393.084 \\ 5.500 & 7.389 \\ 4.047 & 5.977 \\ 0.110 & 0.230 \\ -0.004 & 0.049 \\ 7.515 & 9.452 \\ 0.007 & 0.083 \\ 0.000 & 1.000 \\ 0.132 & 0.478 \\ 0.258 & 0.715 \\ 0.000 & 1.000 \\ 0.000 & 0.012 \\ 2.564 & 6.164 \\ 0.184 & 0.420 \\ 0.001 & 0.079 \\ 0.000 & 1.000 \\ 1.000 & 1.000 \\ 0.035 & 0.316\end{array}$

All continuous tax and control variables are winsorized at the 1 percent and 99 percent levels to mitigate the influence of outliers.

This table presents summary statistics for the variables used in the empirical analyses. The sample is comprised of 7,028 firm-years spanning fiscal years 1993-2011.

Variable Definitions:

$B T D=$ pretax income less minority interest and estimated taxable income;

SHELTER = tax sheltering likelihood, computed following Wilson (2009);

CEO Delta $($ Vega $)=$ change in the dollar value of the CEO's option portfolio given a $\$ 1$ (0.01 unit) increase in stock price (volatility), reported in thousands;

$R O A=$ return on assets, computed as pretax book income (Compustat $\left.\mathrm{PI}_{i, t}\right)$ divided by lagged total assets $\left(\right.$ Compustat $\left.\mathrm{AT}_{i, t-1}\right) ;$

$A C C=$ performance-matched pretax discretionary accruals, computed following Frank et al. (2009);

$S I Z E=$ firm size, computed as the natural logarithm of sales (Compustat $\left.\mathrm{SALE}_{i, t}\right)$;

$F I=$ foreign income, computed as pretax income from foreign operations (Compustat $\left.\mathrm{PIFO}_{i, t}\right)$ divided by lagged total assets $\left(\right.$ Compustat $\left.\mathrm{AT}_{i, t-1}\right)$; $E Q I N C=1$ if equity in earnings (Compustat $\mathrm{ESUB}_{i, t}$ ) is positive;

$I N T A N=$ reported intangibles $\left(\right.$ Compustat INTAN $\left._{i, t}\right)$ divided by lagged total assets $\left(\right.$ Compustat $\left.\mathrm{AT}_{i, t-1}\right)$;

$P P E=$ net property, plant, and equipment (Compustat $\left.\mathrm{PPENT}_{i, t}\right)$ divided by lagged total assets (Compustat $\left.\mathrm{AT}_{i, t}\right)$;

$N O L=$ an indicator variable equal to 1 if the firm reports a positive tax loss carryforward during the year (Compustat TLCF $\left._{i, t}\right) ;$

$\triangle N O L=$ change in net operating loss carryforward divided by lagged assets $\left(\left(\right.\right.$ Compustat $\left.\left.\mathrm{TLCF}_{i, t}-\mathrm{TLCF}_{i, t-1}\right) / \mathrm{AT}_{i, t-1}\right)$;

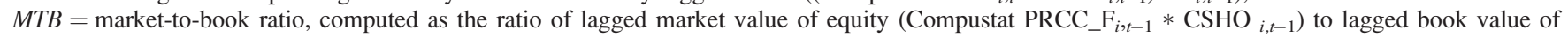
equity (Compustat $\mathrm{CEQ}_{i, t-1}$ );

$L E V=$ leverage, computed as total long-term debt (Compustat $\left.\operatorname{DLTT}_{i, t}\right)$ divided by lagged total assets $\left(\right.$ Compustat $\left.\mathrm{AT}_{i, t-1}\right)$;

$R \& D=$ research and development activity, computed by scaling $\mathrm{R} \& \mathrm{D}$ expense (Compustat $\left.\mathrm{XRD}_{i, t}\right)$ by lagged total assets $\left(\right.$ Compustat $\left.\mathrm{AT}_{i, t-1}\right)$;

$P R I O R L I T 3=1$ if the firm is a defendant in a lawsuit during the current or previous three years;

TAXHAV3 $=1$ if the firm discloses material operations in a known tax haven during the current or previous three years; and

$\sigma(E T R)=$ volatility of the book effective tax rate (Compustat TXT/PI) over the current and previous four years.

similar constructs. Our difference-in-differences estimator, GCFIRM $*$ POST, is positively and significantly correlated with both BTD and SHELTER, suggesting some initial univariate support for the hypothesis that GC ascension is associated with a more aggressive tax policy. Many of the remaining correlations are significant, providing some support for their inclusion in the model and, with a few exceptions, most of the remaining correlations are small. ${ }^{27}$

${ }^{27}$ We investigate the extent to which multicollinearity may influence our results using variance inflation factors (VIFs). In untabulated tests, we confirm that the VIFs for these variables are all less than 3.7, well below thresholds of concern (Kennedy 2008). 
TABLE 3

Correlations

Panel A: Correlation Variables $B T D_{t}$ to $A C C_{t}$

\begin{tabular}{|c|}
\hline Variable \\
\hline 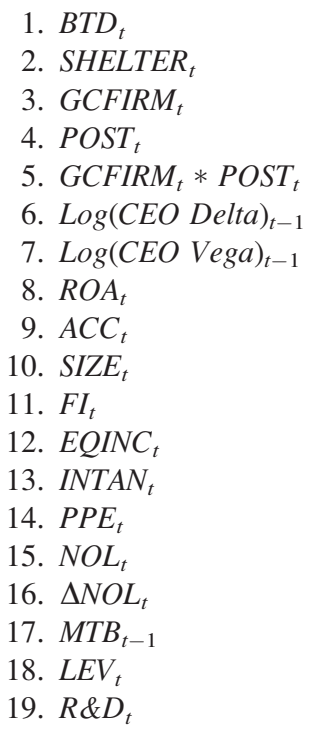 \\
\hline
\end{tabular}

\begin{tabular}{|c|c|c|}
\hline 1 & 2 & 3 \\
\hline & 0.37 & 0.03 \\
\hline 0.35 & & 0.07 \\
\hline 0.01 & 0.07 & \\
\hline 0.07 & 0.15 & -0.01 \\
\hline 0.06 & 0.14 & 0.60 \\
\hline 0.07 & 0.30 & -0.01 \\
\hline 0.06 & 0.37 & 0.07 \\
\hline 0.28 & 0.21 & -0.02 \\
\hline 0.16 & 0.03 & 0.01 \\
\hline 0.00 & 0.52 & 0.09 \\
\hline 0.25 & 0.52 & 0.00 \\
\hline 0.01 & 0.15 & 0.02 \\
\hline-0.01 & 0.12 & 0.07 \\
\hline 0.14 & -0.11 & -0.03 \\
\hline 0.04 & 0.16 & 0.02 \\
\hline$-\mathbf{0 . 0 3}$ & 0.19 & 0.01 \\
\hline 0.11 & 0.18 & 0.03 \\
\hline 0.01 & -0.07 & 0.05 \\
\hline 0.10 & 0.30 & 0.02 \\
\hline
\end{tabular}

\begin{tabular}{rrr}
\multicolumn{1}{c}{$\boldsymbol{4}$} & & \multicolumn{1}{c}{$\mathbf{5}$} \\
$\mathbf{0 . 0 8}$ & & $\mathbf{0 . 0 7}$ \\
$\mathbf{0 . 1 5}$ & & $\mathbf{0 . 1 4}$ \\
-0.01 & & $\mathbf{0 . 6 0}$ \\
& & $\mathbf{0 . 6 0}$ \\
$\mathbf{0 . 6 0}$ & & \\
$\mathbf{0 . 1 1}$ & & $\mathbf{0 . 0 7}$ \\
$\mathbf{0 . 1 8}$ & & $\mathbf{0 . 1 5}$ \\
$-\mathbf{0 . 0 7}$ & & $-\mathbf{0 . 0 6}$ \\
$\mathbf{0 . 0 4}$ & & $\mathbf{0 . 0 2}$ \\
$\mathbf{0 . 1 1}$ & & $\mathbf{0 . 1 4}$ \\
$\mathbf{0 . 1 3}$ & & $\mathbf{0 . 0 6}$ \\
$\mathbf{0 . 0 4}$ & & $\mathbf{0 . 0 4}$ \\
$\mathbf{0 . 1 8}$ & $\mathbf{0 . 1 7}$ \\
$-\mathbf{0 . 1 2}$ & $-\mathbf{0 . 0 7}$ \\
$\mathbf{0 . 2 0}$ & $\mathbf{0 . 1 2}$ \\
$\mathbf{0 . 0 3}$ & 0.02 \\
$-\mathbf{0 . 0 3}$ & 0.01 \\
$-\mathbf{0 . 0 3}$ & 0.02 \\
-0.02 & -0.01
\end{tabular}

\begin{tabular}{r}
\multicolumn{1}{c}{6} \\
\hline $\mathbf{0 . 0 8}$ \\
$\mathbf{0 . 3 6}$ \\
0.00 \\
$\mathbf{0 . 1 1}$ \\
$\mathbf{0 . 0 8}$ \\
\\
$\mathbf{0 . 6 0}$ \\
$\mathbf{0 . 1 7}$ \\
$-\mathbf{0 . 0 3}$ \\
$\mathbf{0 . 3 2}$ \\
$\mathbf{0 . 1 3}$ \\
$\mathbf{0 . 0 3}$ \\
$\mathbf{0 . 1 0}$ \\
$-\mathbf{0 . 0 4}$ \\
0.02 \\
0.01 \\
$\mathbf{0 . 1 9}$ \\
$-\mathbf{0 . 0 3}$ \\
$\mathbf{0 . 1 1}$
\end{tabular}

\begin{tabular}{r}
\multicolumn{1}{c}{7} \\
\hline $\mathbf{0 . 0 7}$ \\
$\mathbf{0 . 4 3}$ \\
$\mathbf{0 . 0 8}$ \\
$\mathbf{0 . 2 1}$ \\
$\mathbf{0 . 1 8}$ \\
$\mathbf{0 . 6 1}$ \\
\\
0.01 \\
0.01 \\
$\mathbf{0 . 3 6}$ \\
$\mathbf{0 . 1 7}$ \\
$\mathbf{0 . 1 1}$ \\
$\mathbf{0 . 1 8}$ \\
$-\mathbf{0 . 1 0}$ \\
$\mathbf{0 . 0 9}$ \\
$\mathbf{0 . 0 3}$ \\
$\mathbf{0 . 1 0}$ \\
0.01 \\
$\mathbf{0 . 1 3}$
\end{tabular}

\begin{tabular}{r}
\multicolumn{1}{c}{8} \\
\hline 0.25 \\
0.23 \\
-0.03 \\
-0.06 \\
-0.05 \\
0.22 \\
0.03 \\
\\
0.00 \\
-0.10 \\
0.25 \\
-0.09 \\
-0.09 \\
0.03 \\
-0.13 \\
-0.05 \\
0.38 \\
-0.25 \\
0.21
\end{tabular}

\begin{tabular}{r}
\multicolumn{1}{c}{9} \\
\hline $\mathbf{0 . 1 5}$ \\
0.00 \\
0.01 \\
$\mathbf{0 . 0 4}$ \\
0.02 \\
$-\mathbf{0 . 0 6}$ \\
-0.01 \\
$-\mathbf{0 . 0 4}$ \\
\\
0.00 \\
$-\mathbf{0 . 0 2}$ \\
$\mathbf{0 . 0 8}$ \\
$-\mathbf{0 . 0 8}$ \\
$\mathbf{0 . 1 0}$ \\
0.00 \\
0.01 \\
$-\mathbf{0 . 0 7}$ \\
$\mathbf{0 . 0 6}$ \\
$-\mathbf{0 . 1 7}$
\end{tabular}

Panel B: Correlation Variables $S I Z E_{t}$ to $R \& D_{t}$

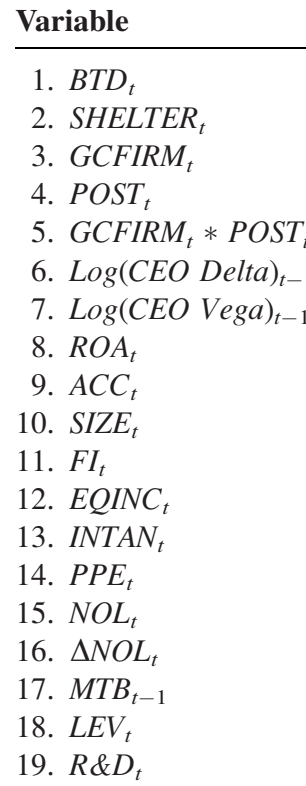

\begin{tabular}{r}
\multicolumn{1}{c}{$\mathbf{1 0}$} \\
\hline 0.00 \\
$\mathbf{0 . 5 3}$ \\
$\mathbf{0 . 0 9}$ \\
$\mathbf{0 . 1 2}$ \\
$\mathbf{0 . 1 5}$ \\
$\mathbf{0 . 4 3}$ \\
$-\mathbf{0 . 0 7}$ \\
0.01 \\
\\
$\mathbf{0 . 1 5}$ \\
$\mathbf{0 . 2 1}$ \\
$\mathbf{0 . 1 0}$ \\
$-\mathbf{0 . 0 3}$ \\
$\mathbf{0 . 0 4}$ \\
0.00 \\
$\mathbf{0 . 0 7}$ \\
$\mathbf{0 . 1 2}$ \\
$-\mathbf{0 . 0 9}$
\end{tabular}

\begin{tabular}{r}
\multicolumn{1}{c}{11} \\
\hline 0.14 \\
0.70 \\
0.02 \\
0.13 \\
0.09 \\
0.12 \\
0.23 \\
0.12 \\
-0.01 \\
0.18 \\
0.06 \\
0.03 \\
-0.12 \\
0.11 \\
0.03 \\
0.23 \\
-0.10 \\
0.31
\end{tabular}

\begin{tabular}{r}
\multicolumn{1}{c}{$\mathbf{1 2}$} \\
\hline 0.01 \\
0.02 \\
$\mathbf{0 . 0 4}$ \\
$\mathbf{0 . 0 4}$ \\
$\mathbf{0 . 0 4}$ \\
$\mathbf{0 . 1 3}$ \\
$-\mathbf{0 . 0 9}$ \\
$\mathbf{0 . 0 9}$ \\
$\mathbf{0 . 2 1}$ \\
$\mathbf{0 . 1 0}$ \\
0.00 \\
$\mathbf{0 . 0 9}$ \\
$\mathbf{0 . 0 4}$ \\
0.00 \\
$-\mathbf{0 . 0 3}$ \\
$\mathbf{0 . 1 3}$ \\
$-\mathbf{0 . 0 6}$
\end{tabular}

\begin{tabular}{rrr}
\multicolumn{1}{c}{$\mathbf{1 3}$} & & \multicolumn{1}{c}{$\mathbf{1 4}$} \\
-0.01 & & $\mathbf{0 . 0 8}$ \\
$\mathbf{0 . 1 5}$ & & $-\mathbf{0 . 1 1}$ \\
$\mathbf{0 . 0 8}$ & & -0.02 \\
$\mathbf{0 . 2 2}$ & & $-\mathbf{0 . 1 4}$ \\
$\mathbf{0 . 1 9}$ & & $-\mathbf{0 . 0 9}$ \\
$\mathbf{0 . 1 3}$ & & $-\mathbf{0 . 0 5}$ \\
$\mathbf{0 . 2 5}$ & & $-\mathbf{0 . 1 3}$ \\
$-\mathbf{0 . 1 1}$ & $\mathbf{0 . 0 5}$ \\
$-\mathbf{0 . 1 0}$ & $\mathbf{0 . 1 5}$ \\
$\mathbf{0 . 1 5}$ & & 0.01 \\
$\mathbf{0 . 1 4}$ & $-\mathbf{0 . 1 6}$ \\
$\mathbf{0 . 0 3}$ & $\mathbf{0 . 1 3}$ \\
& $-\mathbf{0 . 4 0}$ \\
$-\mathbf{0 . 3 3}$ & \\
$\mathbf{0 . 1 2}$ & $-\mathbf{0 . 1 0}$ \\
$\mathbf{0 . 0 7}$ & 0.01 \\
-0.01 & $-\mathbf{0 . 0 5}$ \\
$\mathbf{0 . 2 7}$ & $\mathbf{0 . 3 1}$ \\
0.00 & $-\mathbf{0 . 2 5}$
\end{tabular}

\begin{tabular}{r}
\multicolumn{1}{c}{$\mathbf{1 5}$} \\
\hline $\mathbf{0 . 0 5}$ \\
0.16 \\
0.02 \\
$\mathbf{0 . 2 0}$ \\
0.02 \\
$\mathbf{0 . 1 0}$ \\
$-\mathbf{0 . 1 4}$ \\
-0.01 \\
$\mathbf{0 . 0 6}$ \\
$\mathbf{0 . 1 6}$ \\
$\mathbf{0 . 0 4}$ \\
$\mathbf{0 . 1 3}$ \\
$-\mathbf{0 . 1 2}$ \\
\\
$\mathbf{0 . 1 5}$ \\
-0.02 \\
$\mathbf{0 . 0 6}$ \\
$\mathbf{0 . 0 6}$
\end{tabular}

\begin{tabular}{r}
\multicolumn{1}{c}{$\mathbf{1 6}$} \\
\hline$-\mathbf{0 . 0 6}$ \\
$\mathbf{0 . 1 1}$ \\
0.00 \\
$\mathbf{0 . 0 5}$ \\
0.02 \\
0.00 \\
$\mathbf{0 . 0 3}$ \\
$-\mathbf{0 . 0 8}$ \\
0.01 \\
$\mathbf{0 . 0 3}$ \\
$\mathbf{0 . 0 3}$ \\
0.01 \\
$\mathbf{0 . 0 5}$ \\
-0.01 \\
$\mathbf{0 . 1 6}$ \\
-0.02 \\
$\mathbf{0 . 0 7}$ \\
0.02
\end{tabular}

\begin{tabular}{r}
\multicolumn{1}{c}{$\mathbf{1 7}$} \\
\hline $\mathbf{0 . 1 1}$ \\
$\mathbf{0 . 2 9}$ \\
0.01 \\
$-\mathbf{0 . 1 0}$ \\
$-\mathbf{0 . 0 5}$ \\
$\mathbf{0 . 3 5}$ \\
$\mathbf{0 . 2 0}$ \\
$\mathbf{0 . 5 3}$ \\
$-\mathbf{0 . 1 2}$ \\
$\mathbf{0 . 1 0}$ \\
$\mathbf{0 . 1 8}$ \\
$-\mathbf{0 . 0 3}$ \\
0.01 \\
-0.02 \\
$-\mathbf{0 . 0 5}$ \\
-0.01 \\
\\
$\mathbf{0 . 0 4}$ \\
$\mathbf{0 . 2 5}$
\end{tabular}

\begin{tabular}{r}
\multicolumn{1}{c}{$\mathbf{1 8}$} \\
\hline 0.00 \\
$-\mathbf{0 . 0 5}$ \\
$\mathbf{0 . 0 5}$ \\
-0.01 \\
$\mathbf{0 . 0 4}$ \\
$-\mathbf{0 . 0 5}$ \\
$\mathbf{0 . 0 4}$ \\
$-\mathbf{0 . 3 0}$ \\
$\mathbf{0 . 0 8}$ \\
$\mathbf{0 . 1 9}$ \\
$-\mathbf{0 . 0 6}$ \\
$\mathbf{0 . 1 5}$ \\
$\mathbf{0 . 2 0}$ \\
$\mathbf{0 . 2 7}$ \\
$\mathbf{0 . 0 6}$ \\
$\mathbf{0 . 0 6}$ \\
$-\mathbf{0 . 0 8}$ \\
\\
$-\mathbf{0 . 2 0}$
\end{tabular}

\begin{tabular}{r}
\multicolumn{1}{c}{$\mathbf{1 9}$} \\
\hline $\mathbf{0 . 0 8}$ \\
$\mathbf{0 . 4 0}$ \\
$\mathbf{0 . 0 3}$ \\
0.00 \\
0.00 \\
$\mathbf{0 . 0 9}$ \\
$\mathbf{0 . 1 7}$ \\
$\mathbf{0 . 1 0}$ \\
$-\mathbf{0 . 1 5}$ \\
$-\mathbf{0 . 0 4}$ \\
$\mathbf{0 . 4 1}$ \\
0.02 \\
$\mathbf{0 . 1 2}$ \\
$-\mathbf{0 . 2 8}$ \\
$\mathbf{0 . 0 8}$ \\
-0.01 \\
$\mathbf{0 . 3 0}$ \\
$-\mathbf{0 . 1 9}$
\end{tabular}

Bold coefficients denote significance at the 5 percent level or less using a two-sided test.

This table presents correlation coefficients for the variables used to specify Equation (1). Pearson (Spearman) correlations are reported below (above) the diagonal. 


\section{Propensity Score Matching}

\section{Determinants of General Counsel Ascension}

In this section, we use propensity score matching to form a matched sample of firms that appear similar on variables that explain GC ascension, but could also be correlated with tax policy, such as litigation and tax haven operations, among others. We use a parsimonious model to explain GC ascension, using variables that are likely to have significant influence in the decision to ascend a corporate GC, as well as corporate tax policy. Variables used to estimate the likelihood of ascension are discussed below.

PRIORLIT3 equals 1 if the firm is a defendant in litigation during the current and previous three fiscal years. TAXHAV3 equals 1 if the firm reports material operations in a known tax haven. ${ }^{28}$ Return on assets $(R O A)$ and performance-matched pretax discretionary accruals $(A C C)$ capture the effects of profitability and earnings management on the ascension of a corporate GC. Finally, we include CEO equity incentives ( $\log (C E O$ Delta $), \log (C E O$ Vega $)$ ) to control for compensationinduced incentives for risk-taking and a CEO's proclivity to ascend a sympathetic GC. We also control for the volatility of the firm's generally accepted accounting principles (GAAP) effective tax rate over the current and previous four years $(\sigma(E T R)){ }^{29}$ Table 4 reports the results.

Panel A of Table 4 reports results from estimating our logistic regression. Results suggest that a firm's involvement in prior litigation (PRIORLIT3) and material operations in a known tax haven (TAXHAV3) are positively associated with GC ascension ( $\mathrm{p}$-value $<0.01$ ). Although the current level of earnings management $(A C C)$ is insignificant ( $\mathrm{p}$-value $=0.529$ ), the remaining variables are significant. Specifically, firms with lower profitability are more likely to ascend their GCs to top management $(R O A$, p-value $=0.001)$, and firms led by CEOs with greater compensation-induced incentives for risk-taking are more likely to ascend their corporate GCs $(\log (C E O$ Vega $)$, p-value $=0.007)$. Interestingly, firms with more persistent effective tax rates are more likely to ascend their GCs $(\sigma(E T R)$, p-value $=0.063)$. Finally, the area under the ROC curve is 0.720 , which suggests reasonable discriminant ability (Hosmer and Lemeshow 2000).

\section{Covariate Balance}

We match firms who have ascended their GC to top management (treatment firms) to firms who have never ascended a corporate GC (control firms) using nearest-neighbor matching without replacement. This procedure yields a sample of 337 matched pairs. Table 4, Panel B reports the covariate balances across the variables used to estimate our logit model. With the exception of the volatility of ETR $(\sigma(E T R))$, results confirm that treatment firms and control firms are similar on the overall propensity score and on most individual dimensions. ${ }^{30} \mathrm{Next}$, we estimate our difference-in-differences regressions (Equation (1)) on this matched sample of firms to investigate whether GC ascension is associated with a shift in corporate tax policy when compared to a matched sample of similar firms. ${ }^{31}$ Table 5 reports the results.

\section{Main Results}

Table 5 reports results from estimating Equation (1) over our matched sample of treatment and control firms. As discussed previously, our difference-in-differences estimator is GCFIRM $* P O S T$, which captures the incremental change in corporate tax policy observed among firms who have ascended their GCs to top management. Results support the general patterns in Figure 1 , as well as our pairwise correlations, and confirm that GC ascension is associated with a significant increase in both book-tax differences $(B T D)$ and tax sheltering likelihood (SHELTER). Specifically, the coefficient estimate on GCFIRM* POST in the $B T D$ regression is positive and highly significant (Column (1): Estimate $=0.005$, p-value $=0.008)$. Turning to the SHELTER regression, we also observe a positive and significant coefficient loading on GCFIRM $*$ POST (Column (2): Estimate $=0.010$, p-value $=0.053) .{ }^{32}$ With few exceptions, most of the remaining coefficient estimates are significant and appropriately signed. ${ }^{33}$

${ }^{28}$ Data procedures used to construct this measure are found in Dyreng and Lindsey (2009). We thank Scott Dyreng for sharing the data.

29 We ensure that control firms have never ascended a GC to top management at any point in the sample and we require each firm to have available data immediately before (year $t-1)$ and immediately after (year $t+1)$ in order to enter the logit model. Further, the volatility of the book effective tax rate $(\sigma(E T R))$ requires five continuous years of data. These additional data constraints result in a smaller sample to estimate the logit $(\mathrm{n}=6,903)$.

30 We also confirm that matched pairs are balanced on both fiscal year and industry.

${ }^{31}$ To mitigate the possible influence of the imbalance between treatment and control groups, we also estimate Equation $(1)$ with $\sigma(E T R)$ as an additional control variable. Untabulated tests reveal that our results actually become a bit stronger.

32 One concern with the SHELTER specification is that five of the inputs used to construct SHELTER are also control variables (ROA, FI, SIZE, LEV, and $R \& D$ ), although we measure them in a slightly different way (for example, we use a continuous measure of foreign income in lieu of a dummy variable). In untabulated tests, we reestimate the regression excluding these variables and continue to find a positive and significant (one-tailed) coefficient on GCFIRM $*$ POST.

${ }^{33}$ There is no estimated coefficient for GCFIRM as it is absorbed into the firm fixed effect. 
TABLE 4

Determinants of GC Ascension and Covariate Balance

Panel A: Determinants of GC Ascension

\begin{tabular}{lccc} 
& \multirow{2}{\text{Exp.}}{} & \multicolumn{2}{c}{ GC_ASCENSION $_{\boldsymbol{t}}$} \\
\cline { 2 - 4 } & Sign & Estimate & p-value \\
\cline { 2 - 4 } & $?$ & -14.653 & 0.000 \\
Intercept $_{\text {PRIORLIT3 }_{t}}$ & + & 0.344 & 0.019 \\
TAXHAV3 $_{t}$ & + & 0.517 & 0.001 \\
ROA $_{t}$ & $?$ & -2.897 & 0.001 \\
ACC & $?$ & 0.708 & 0.529 \\
$\log (\text { CEO Delta })_{t-1}$ & $?$ & -0.172 & 0.000 \\
Log(CEO Vega $)_{t-1}$ & $?$ & 0.130 & 0.007 \\
$\sigma(E T R)_{t}$ & $?$ & -0.124 & 0.063 \\
Time dummies? & & Included & \\
Industry dummies? & & Included & \\
Observations & & 6,903 & \\
Pseudo R & & 0.084 & \\
Area under the ROC curve & & 0.720 &
\end{tabular}

Panel B: Covariate Balance

(1)

\begin{tabular}{cr}
\hline \multicolumn{2}{c}{ Treatment Group } \\
\hline \multicolumn{1}{c}{$\mathbf{n}$} & \multicolumn{1}{c}{ Mean } \\
337 & 0.087 \\
337 & 0.519 \\
337 & 0.599 \\
337 & 0.118 \\
337 & -0.011 \\
337 & 5.253 \\
337 & 3.782 \\
337 & 0.183
\end{tabular}

(2)

\begin{tabular}{lrr}
\hline \multicolumn{2}{c}{ Control Group } & \\
\cline { 1 - 1 } $\mathbf{n}$ & Mean & p-value \\
337 & 0.087 & 0.962 \\
337 & 0.499 & 0.590 \\
337 & 0.585 & 0.696 \\
337 & 0.120 & 0.814 \\
337 & -0.004 & 0.135 \\
337 & 5.166 & 0.553 \\
337 & 3.575 & 0.171 \\
337 & 0.107 & 0.011
\end{tabular}

All p-values are two-tailed, and standard errors are clustered by firm.

This table presents a logistic regression of GC ascension (Panel A) and a covariate balance (Panel B) after matching ascending firms to control firms. For brevity, fiscal year and industry dummies are not reported.

Variable definitions are contained in Table 2.

Overall, we interpret these results as consistent with prominent GCs pursuing a more aggressive corporate tax policy. Next, we discuss the results from a number of additional robustness tests.

\section{ADDITIONAL TESTS}

\section{Effective Tax Rates}

In our primary tests, we use BTD and SHELTER to measure the extent to which GC ascension is associated with a shift toward a more aggressive tax policy. In this section, we consider whether GC ascension is associated with a discernable shift in both book and cash effective tax rate measures. The advantage of using these measures is that they are among the most commonly used measures in this stream of research, and if tax strategies being influenced by GC ascension are intended to have an effect on earnings and/or cash flows, then we ought to observe a similar effect on the firm's effective tax rate. The disadvantage to using these measures is that they alone are not sufficient in capturing more aggressive tax policies (Guenther, 
TABLE 5

Difference-in-Differences Regressions

\begin{tabular}{|c|c|c|c|c|c|}
\hline & \multirow{2}{*}{$\begin{array}{l}\text { Exp. } \\
\text { Sign }\end{array}$} & \multicolumn{2}{|c|}{$\begin{array}{c}(1) \\
B T D_{t}\end{array}$} & \multicolumn{2}{|c|}{$\begin{array}{c}(2) \\
\text { SHELTER }\end{array}$} \\
\hline & & Estimate & p-value & Estimate & p-value \\
\hline Intercept & $?$ & 0.024 & 0.018 & -0.032 & 0.250 \\
\hline GCFIRM $_{t}$ & $?$ & & & & \\
\hline $\mathrm{POST}_{t}$ & $?$ & -0.005 & 0.007 & 0.000 & 0.934 \\
\hline GCFIRM $_{t} *$ POST $_{t}$ & $?$ & 0.005 & 0.008 & 0.010 & 0.053 \\
\hline $\log (C E O \text { Delta })_{t-1}$ & - & -0.001 & 0.012 & 0.000 & 0.867 \\
\hline $\log (C E O \text { Vega })_{t-1}$ & + & 0.000 & 0.544 & 0.003 & 0.013 \\
\hline$R O A_{t}$ & + & 0.185 & 0.000 & 0.681 & 0.000 \\
\hline$A C C_{t}$ & + & 0.121 & 0.000 & 0.205 & 0.000 \\
\hline$S I Z E_{t}$ & $?$ & -0.006 & 0.000 & 0.078 & 0.000 \\
\hline$F I_{t}$ & + & 0.267 & 0.000 & 0.929 & 0.000 \\
\hline$E Q I N C_{t}$ & + & -0.001 & 0.467 & 0.000 & 0.959 \\
\hline$I_{N T A N}$ & + & 0.010 & 0.007 & 0.053 & 0.000 \\
\hline$P P E_{t}$ & + & -0.001 & 0.887 & -0.027 & 0.079 \\
\hline $\mathrm{NOL}_{t}$ & + & 0.004 & 0.002 & 0.013 & 0.001 \\
\hline$\Delta N O L_{t}$ & - & -0.047 & 0.001 & 1.304 & 0.000 \\
\hline$M T B_{t-1}$ & $?$ & 0.000 & 0.235 & -0.002 & 0.000 \\
\hline$L E V_{t}$ & - & 0.007 & 0.093 & -0.090 & 0.000 \\
\hline$R \& D_{t}$ & + & -0.147 & 0.000 & 0.048 & 0.540 \\
\hline Year fixed effects? & & Included & & Included & \\
\hline Firm fixed effects? & & Included & & Included & \\
\hline Observations & & 7,028 & & 7,028 & \\
\hline $\mathrm{R}^{2}$ & & 0.481 & & 0.846 & \\
\hline
\end{tabular}

Coefficients of interest are in bold, and all p-values are two-tailed.

This table presents difference-in-differences regressions for our full sample. For brevity, fiscal year and firm dummies are not reported.

Variable definitions are contained in Table 2.

Matsunaga, and Williams 2012). Thus, we interpret our results from this section along with our primary results using BTD and SHELTER and not as standalone results.

Untabulated tests reveal a similar pattern. Specifically, coefficient estimates on GCFIRM $*$ POST are negative and highly statistically significant, suggesting that GC ascension is associated with a reduction in both the book (ETR regression, Estimate $=-0.017, \mathrm{p}$-value $=0.004)$ and cash effective tax rate $(C E T R$ regression, Estimate $=-0.024$, p-value $<0.010) .{ }^{34}$ These results are consistent with the results reported in Table 5; namely, that GC ascension is associated with a discernable shift in corporate tax policy toward a reduction in tax liabilities that have an impact on both GAAP earnings, as well as cash flows. Thus, our primary results are confirmed using alternative tax measures. ${ }^{35}$

\section{Placebo Tests}

In the previous section, we presented evidence that GC ascension is associated with a shift toward a more aggressive tax policy. In this section, we examine the robustness of our findings by performing a placebo test whereby we replace GC ascension with a chief marketing officer (CMO) ascension - an executive who ex ante would have almost no influence over tax planning. We reestimate our difference-in-differences regressions using a larger pooled sample, and omitting firms that have ever ascended a GC to the top management team, thereby providing a clean placebo test. ${ }^{36}$ Untabulated tests reveal no relation

\footnotetext{
34 Lower values of the book or cash effective tax rate imply greater tax avoidance.

35 As a further robustness check, we omit firm-years in which there was a change in CEO and find that our results continue to hold across all of our tax aggressiveness measures.

36 Consistent with our earlier definitions, we require CMOs to be present in the top management team for at least two years in order to be considered a "CMO ascension."
} 
between CMO ascension and subsequent tax policy. Specifically, we observe insignificant coefficients on subsequent tax policy in the BTD and SHELTER regressions, as well as the book and cash effective tax rate regressions, suggesting that our initial results are not spuriously correlated with some factor associated with any change in the top executive team.

\section{General Counsel Removals}

We also examine whether our results are sensitive to the removal of the GC from the top management team. One argument might be that the removal of the GC could have the opposite effect (a less aggressive tax policy). On the other hand, the GC could be replaced with another executive who is also interested in pursuing an aggressive corporate tax policy. Relatedly, the tax policies adopted during the GC's tenure in the upper echelon may still be in effect, which could preclude us from observing an opposite result. Nevertheless, we explore these empirical possibilities by reestimating a pooled difference-in-differences regression with firm fixed effects and redefining POST to equal 1 for years after the GC has left the top management team.

Untabulated results suggest that GC removal is associated with a significant reduction in book-tax differences $(B T D$ regression, Estimate $=-0.002, \mathrm{p}$-value $=0.095)$ and an insignificant reduction in tax sheltering likelihood (SHELTER regression, Estimate $=-0.002$, p-value $=0.581$ ). These results provide some support for the notion that the GC's influence over tax policy ends upon removal from the top management team.

\section{General Counsel Characteristics}

In this section, we hand-collect data on a random sample of over $200 \mathrm{GCs}$ who have ascended to the top management team during fiscal years 2009-2011 in order to capture various characteristics of these GCs and to better observe possible trade-offs a firm is making between GC ascension and the removal of an existing manager. Table 6 provides a graph and some descriptive statistics for this hand-collected sample.

The graph in Table 6, Panel A depicts the distribution of managers being replaced by the GC. It is clear that operations (60.3 percent) was the most common category replaced by the GC, followed by accounting (20.1 percent). The remaining categories were replaced less often, perhaps because it is less common to observe IT, marketing, or HR in the top management team. The distribution suggests that legal issues could be becoming more important than operations, thus necessitating the need for a prominent GC in the top executive team. However, our sample size is small and it is possible that operations, through other executive team members, remains adequately represented in the executive team. Thus, we caution the reader from overgeneralizing our results. Nevertheless, these descriptive results are informative.

Table 6, Panel B contains descriptive statistics on various GC characteristics for our hand-collected sample. The average $\mathrm{GC}$ has been with the firm for over six years before ascending to the top management team (GC TENURE), and the majority of GCs who ascend are promoted internally, as the average ascension from an external hire is observed in only 18 percent of instances (NEWAPPT). Approximately 21 percent of GCs have an M.B.A. or LL.M. degree, or prior tax or accounting experience (TAXACCEXP), and the majority (65.3 percent) of GCs have graduated from a top-tier law school (TOPSCHOOL). Finally, over 60 percent of GCs have prior experience as a corporate GC (GCEXP), and most (80.8 percent) of them have prior experience with a law firm (LAWFIRMEXP).

We further examine whether our results are stronger when the GC has prior accounting and/or tax experience by interacting our difference-in-differences estimator GCFIRM * POST with TAXACCEXP. Untabulated results reveal a positive, but insignificant, coefficient on this interaction in both the BTD and SHELTER regressions; however, we continue to observe a positive and significant coefficient loading on GCFIRM $*$ POST. We attribute the insignificant results on the interaction with TAXACCEXP to low power as we only have observations on TAXACCEXP for 2009.

\section{Governance}

Our main results support the hypothesis that prominent GCs appear to be active in pursuing a more aggressive corporate tax policy. In this section, we examine the possibility that our results could be concentrated among firms with weaker corporate governance. Using the antitakeover provisions index of Gompers, Ishii, and Metrick (2003)—referred to as the "GINDEX"we reestimate our difference-in-differences regressions with interactions between GCFIRM $*$ POST and BADGOV, which is a dummy variable that captures bad governance. ${ }^{37}$ These terms capture the incremental effect of GC ascensions on subsequent tax aggressiveness and firms who ascend their GCs in general for firms with weaker governance, respectively, as higher values of GINDEX reflect weaker corporate governance. Untabulated results confirm our main result, as GCFIRM $*$ POST is significantly positive in each regression ( $\mathrm{p}$-value $<0.01$ ). However, we find no evidence that our result is magnified, or in any

\footnotetext{
${ }^{37} B A D G O V$ equals 1 if the GINDEX is greater than 9 (sample median). We address missing observations by including a dummy variable equal to 1 if the firm is not included in the GINDEX data. We then set missing GINDEX observations equal to 0.
} 
TABLE 6

GC Characteristics

Panel A: Category Replaced

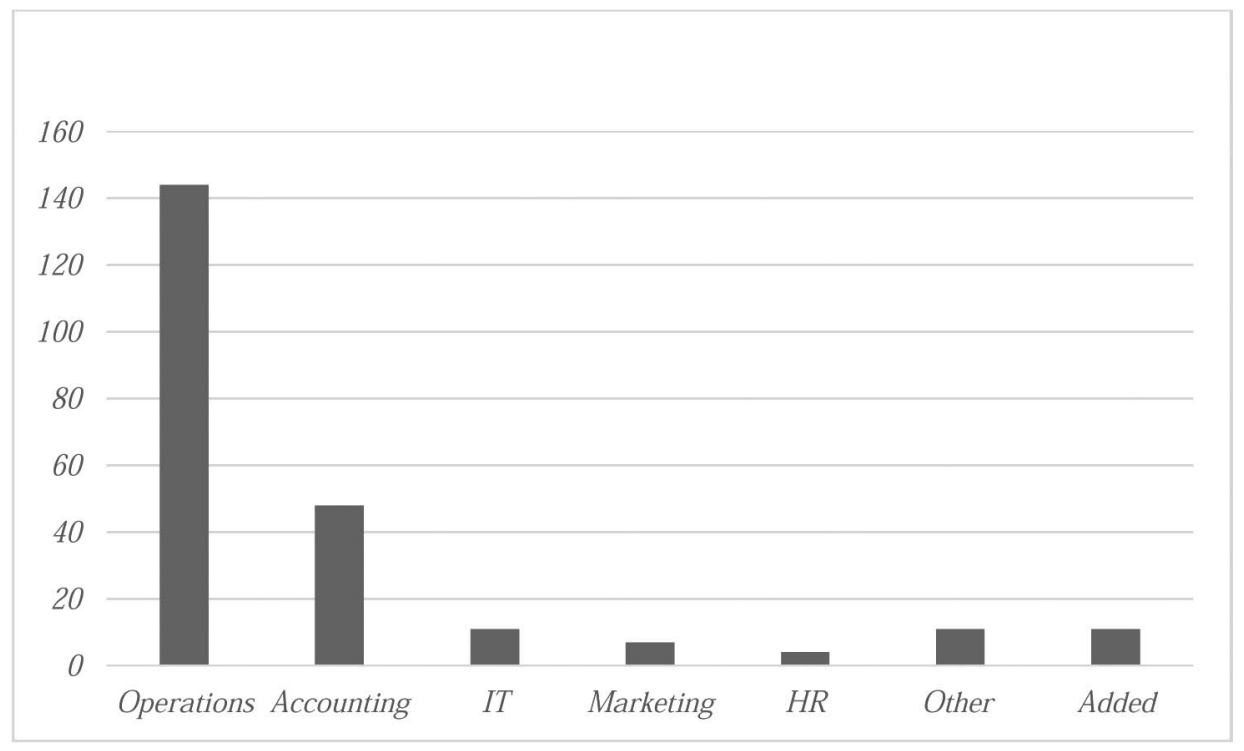

Panel B: Descriptive Statistics

\begin{tabular}{|c|c|c|c|c|c|c|}
\hline Variable & $\mathbf{n}$ & Mean & Std. Dev. & 10th Pctl. & 50th Pctl. & 90th Pctl. \\
\hline GC TENURE & 239 & 6.707 & 6.408 & 1.000 & 5.000 & 14.000 \\
\hline NEWAPPT & 239 & 0.180 & 0.385 & 0.000 & 0.000 & 1.000 \\
\hline ТАХАССЕХР & 239 & 0.205 & 0.405 & 0.000 & 0.000 & 1.000 \\
\hline TOPSCHOOL & 239 & 0.653 & 0.477 & 0.000 & 1.000 & 1.000 \\
\hline$G C E X P$ & 239 & 0.607 & 0.490 & 0.000 & 1.000 & 1.000 \\
\hline LAWFIRMEXP & 239 & 0.808 & 0.395 & 0.000 & 1.000 & 1.000 \\
\hline
\end{tabular}

This table presents descriptive statistics of GC characteristics for a random sample of 239 GCs for which we are able to obtain data during $2009-2011$. Panel A depicts the distribution of the management positions replaced when the GC ascends to the top management team.

Panel B reports summary statistics on the tenure of the GC (GC TENURE), whether the GC was hired externally (NEWAPPT), whether the GC has an M.B.A., LL.M., or prior accounting or tax experience (TAXACCEXP), whether the GC graduated from a top-tier law school (TOPSCHOOL), whether the $\mathrm{GC}$ has prior experience as a corporate GC $(P R I O R G C)$, and whether the GC has previously worked for a law firm (LAWFIRMEXP).

way affected, by weak governance. Specifically, we observe a negative coefficient on GCFIRM $*$ POST * BADGOV (significant in the BTD regression), ruling out the possibility that our results are concentrated among poorly governed firms. Overall, we find no clear evidence that weak corporate governance moderates the association between GC ascension and the shift toward a more aggressive corporate tax policy.

\section{CONCLUSION}

We examine the role that the corporate GC plays in corporate tax policy. The corporate GC acts as a business advisor to the executive team, a legal advisor to the firm, and an advocate when the firm is faced with legal actions. Recent research has provided evidence that the GC plays a significant role in the firm's financial accounting, reporting, and disclosure policy (Jagolinzer et al. 2011; Kwak et al. 2012; Hopkins et al. 2015). We advance this line of inquiry by focusing on the corporate tax setting, because this stream of research contends that corporate tax aggressiveness can be a risky activity (e.g., Hanlon and Slemrod 2009; Chen et al. 2010; Rego and Wilson 2012; Graham et al. 2014) and GCs are increasingly being relied upon to support the corporate tax function (Duggin 2007; Heineman 2012). We present evidence that GC ascension is associated with greater ex post tax aggressiveness after ascension to top management.

We contribute to several streams of literature. First, our study addresses the call from Hanlon and Heitzman (2010) to document a link between the corporate GC and tax avoidance. Second, Armstrong et al. (2012) examined the link between the 
GC (in addition to other executives) and tax outcomes using a cross-sectional levels approach and did not find any significant results. Our study utilizes a difference-in-differences design, with the ascension of the GC as our identifying event, to test the GC's influence over tax policy. Thus, identifying the appropriate economic event is key to identifying and measuring the executive's influence (if any). In our study, we use the ascension of the GC into top management as the identifying event in which the influence of the corporate GC role as business and legal advisor becomes more salient. Finally, we contribute to the emerging literature on the role of the GC in the firm. There may be other economic events (e.g., mergers and acquisitions, capital structure adjustments, bankruptcy, etc.) that may shed additional light on the role of the GC in corporate accounting, finance, and operations. We look forward to future research to answer these questions.

\section{REFERENCES}

American Bar Association (ABA). 2003. Report of the American Bar Association Task Force on Corporate Responsibility. Available at: http://www.abanet.org/buslaw/corporateresponsibility/final_report.pdf

Armstrong, C., J. Blouin, and D. Larcker. 2012. The incentives for tax planning. Journal of Accounting and Economics 53 (1/2): $391-$ 411.

Armstrong, C., D. Larcker, G. Ormazabal, and D. Taylor. 2013. The relation between equity incentives and misreporting: The role of risktaking incentives. Journal of Financial Economics 109 (August): 327-350.

Association of the Bar of the City of New York. 2006. Report of the Task Force on the Lawyer's Role in Corporate Governance. New York, NY: New York City Bar Association.

Brockman, P., X. Martin, and E. Unlu. 2010. Executive compensation and the maturity structure of corporate debt. Journal of Finance 65 (3): 1123-1161.

Brown, C. 2003. In-house counsel responsibilities in the post-Enron environment. Association of Corporate Counsel Docket 21: 82-107.

Chen, S., X. Chen, Q. Cheng, and T. Shevlin. 2010. Are family firms more tax aggressive than non-family firms? Journal of Financial Economics 95: 41-61.

Cheng, C., H. Huang, Y. Li, and J. Stanfield. 2012. The effect of hedge fund activism on corporate tax avoidance. The Accounting Review 87: $1493-1526$.

Chyz, J. 2013. Personally tax aggressive executives and corporate tax sheltering. Journal of Accounting and Economics 56: 311-328.

Chyz, J., F. Gaertner, A. Kausar, and L. Watson. 2014. Overconfidence and Aggressive Corporate Tax Policy. Working paper, The University of Tennessee, University of Wisconsin, Nanyang Technological University, and University of Florida.

Coles, J., N. Daniel, and L. Naveen. 2006. Managerial incentives and risk taking. Journal of Financial Economics 79: 431-468.

Core, J., and W. Guay. 2002. Estimating the value of employee stock option portfolios and their sensitivities to price and volatility. Journal of Accounting Research 40: 613-630.

Deloitte. 2010. Deloitte Forensic Corporate Counsel Survey 2010. Available at: http://acla.acc.com/aclanews/id/15

Deloitte. 2011. Deloitte Global Corporate Counsel Report 2011. Available at: http://pdfserver.amlaw.com/adfulfillment/Deloitte_Global_ Corp_Counsel_US_Edition_new.pdf

DeMott, D. 2005. The discrete roles of general counsel. Fordham Law Review 74: 955-981.

Desai, M., and D. Dharmapala. 2009. Corporate tax avoidance and firm value. Review of Economics and Statistics 91: $537-546$.

Duggin, S. 2007. The pivotal role of the general counsel in promoting corporate integrity and professional responsibility. St. Louis University Law Journal 51: 989-1042.

Dyreng, S., and B. Lindsey. 2009. Using financial accounting data to examine the effect of foreign operations located in tax havens and other countries on U.S. multinational firms' tax rates. Journal of Accounting Research 47: 1283-1316.

Dyreng, S., M. Hanlon, and E. Maydew. 2008. Long-run corporate tax avoidance. The Accounting Review 83: 61-82.

Dyreng, S., M. Hanlon, and E. Maydew. 2010. The effects of executives on corporate tax avoidance. The Accounting Review 85: 11631189.

Finkelstein, S. 1992. Power in top management teams: Dimensions, measurement, and validation. Academy of Management Journal 35: 505-538.

Fleischer, V. 2006. Options Backdating, Tax Shelters, and Corporate Culture. University of Colorado Law Legal Studies Research Paper No. 06-38. Available at: http://papers.ssrn.com/sol3/papers.cfm?abstract_id=939914

Foley \& Lardner LLP. 2010. Corporate Governance in the "New Normal” Business Environment. Available at: http://www.foley.com/ corporate-governance-in-the-new-normal-business-environment-02-01-2010/

Frank, M., L. Lynch, and S. Rego. 2009. Tax reporting aggressiveness and its relation to aggressive financial reporting. The Accounting Review 84: 467-496.

Goh, B., J. Lee, and J. Ng. 2014. The Composition of Top Management with General Counsel and Tax Avoidance. Working paper, Singapore Management University.

Gompers, P., J. Ishii, and A. Metrick. 2003. Corporate governance and equity prices. Quarterly Journal of Economics 118: 107-155. Graham, J. R., and A. Tucker. 2006. Tax shelters and corporate debt policy. Journal of Financial Economics 81: 563-594. 
Graham, J. R., M. Hanlon, T. Shevlin, and N. Shroff. 2014. Incentives for tax planning and avoidance: Evidence from the field. The Accounting Review 89 (3): 991-1023.

Guenther, D., S. Matsunaga, and B. Williams. 2012. Corporate Tax Aggressiveness and Firm Risk. Working paper, University of Oregon.

Gupta, S., and K. Newberry. 1997. Determinants of the variability in corporate effective tax rates: Evidence from longitudinal data. Journal of Accounting and Public Policy 16: 1-34.

Hanlon, M., and J. Slemrod. 2009. What does tax aggressiveness signal? Evidence from stock price reactions to news about tax shelter involvement. Journal of Public Economics 93: 126-141.

Hanlon, M., and S. Heitzman. 2010. A review of tax research. Journal of Accounting and Economics 50: $127-178$.

Hasan, I., C. Hoi, Q. Wu, and H. Zhang. 2014. Beauty is in the eye of the beholder: The effect of corporate tax avoidance on the cost of bank loans. Journal of Financial Economics 113: 109-130.

Heineman, B. 2010. The General Counsel as Lawyer-Statesman. Harvard Law School Program on the Legal Profession Blue Paper. Available at: http://corpgov.law.harvard.edu/2010/09/05/the-general-counsel-as-lawyer-statesman/

Heineman, B. 2012. The Rise of the General Counsel HBR Blog Network. Available at: http://www.blogs.hbr.org/cs/2012/09/the_rise_of_ the_general_counsel.html

Hopkins, J., E. Maydew, and M. Venkatachalam. 2015. Corporate general counsel and financial reporting quality. Management Science 61 (1): 129-145.

Hosmer, D., and S. Lemeshow. 2000. Applied Logistic Regression. New York, NY: Wiley.

Jagolinzer, A., D. Larcker, and D. Taylor. 2011. Corporate governance and the information content of insider trades. Journal of Accounting Research 49: 1249-1274.

Jennings, R., C. Weaver, and W. Mayew. 2012. The extent of implicit taxes at the corporate level and the effect of TRA 86. Contemporary Accounting Research 29 (4): 1021-1059.

Kennedy, P. 2008. A Guide to Econometrics. Sixth edition. Charlottesville, VA: Blackwell Publishing.

Kim, J., Y. Li, and L. Zhang. 2011. Corporate tax avoidance and stock price crash risk: Firm-level analysis. Journal of Financial Economics 100: 639-662.

Knopf, J., J. Nam, and J. Thornton. 2002. The volatility and price sensitivities of managerial stock option portfolios and corporate hedging. Journal of Finance 57: 801-812.

Koester, A., T. Shevlin, and D. Wangerin. 2014. Does Operational Efficiency Spill Over Onto the Tax Return? Working paper, Georgetown University, University of California, Irvine, and Michigan State University.

Kwak, B., B. Ro, and I. Suk. 2012. Corporate in-house legal counsel as a voluntary governance mechanism and the quality of voluntary disclosure: The case of management earnings forecasts. Journal of Accounting and Economics 54: 19-41.

Law, S., and L. Mills. 2013. Doing the Right Thing: Military Experience and Corporate Tax Avoidance. Working paper, Tilburg University and The University of Texas at Austin.

McGuire, S., T. Omer, and D. Wang. 2012. Tax avoidance: Does tax-specific industry expertise make a difference? The Accounting Review 87: 975-1003.

Mills, L., M. Erickson, and E. Maydew. 1998. Investments in tax planning. Journal of the American Taxation Association 20: 1-20.

Nelson, R., and L. Nielsen. 2000. Cops, counsel, and entrepreneurs: Constructing the role of inside counsel in large corporations. Law and Society Review 34: 457-494.

Olsen, K., and J. Stekelberg. 2016. CEO narcissism and corporate tax sheltering. Journal of the American Taxation Association 38.

Rego, S. 2003. Tax-avoidance activities of U.S. multinational corporations. Contemporary Accounting Research 20: 805-833.

Rego, S., and R. Wilson. 2012. Equity risk incentives and corporate tax aggressiveness. Journal of Accounting Research 50: 775-809.

Rostain, T. 2008. General counsel in the age of compliance: Preliminary findings and new research questions. Georgetown Journal of Legal Ethics 21: 465-490.

Schneider, C. 2003. You have the right to an attorney. CFO.com (August 20). Available at: http://www.cfo.com/article.cfm/3010187/c_ 3036074

Shackelford, D., and T. Shevlin. 2001. Empirical tax research in accounting. Journal of Accounting and Economics 31: $321-387$.

Veasey, E., and C. Di Guglielmo. 2012. Indispensable Counsel: The Chief Legal Officer in the New Reality. Oxford, U.K.: Oxford University Press.

Weisbach, D. 2002. Ten truths about tax shelters. Tax Law Review 55: 215-253.

Wilson, R. 2009. An examination of corporate tax shelter participants. The Accounting Review 84: 969-999.

Winders, P. 2005. Law firm general counsel extravagance of necessity. Professional Lawyer 15: 3-11. 